Stručni rad

DOI: $10.17234 /$ Croatica.42.1

UDK: 81'33:81'36Pranjković, I.

Primljen: 30. XI. 2017.

Prihvaćen: 21. I. 2018.

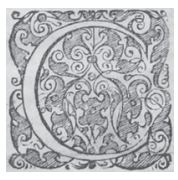

\title{
PRAGMATIKA U GRAMATICI IVE PRANJKOVIĆA
}

\author{
Nikolina Palašić \\ Filozofski fakultet Sveučilišta u Rijeci \\ Odsjek za kroatistiku \\ nikolina.palasic@uniri.hr
}

\begin{abstract}
Na prvi se pogled možda može činiti da gramatički i pragmatički pristup kakvoj jezičnoj pojavnosti nemaju ništa zajedničko te da ih je nemoguće dovesti u kakvu tješnju vezu. Međutim zađemo li dublje u gramatičke opise jezičnih jedinica na morfološkoj i sintaktičkoj razini, doći ćemo do zaključka da je ponekad neke elemente potrebno sagledati i iz šire perspektive, točnije, da je za njihov adekvatan opis potrebno u obzir uzeti i komunikacijski kontekst. Upravo je o tome riječ u ovome radu - u raznovrsnim gramatičkim opisima jezika Ive Pranjkovića pokušat ćemo pronaći one elemente za koje je i sam autor procijenio da im treba pristupiti i iz drugoga kuta promatranja, naime onoga pragmalingvističkog. Takav pristup pojedinim gramatičkim opisima, posebice onima koji se nalaze u gramatičkom priručniku, svakako predstavlja novost na hrvatskoj znanstvenoj sceni.
\end{abstract}

Ključne riječi: pragmatika, gramatika, komunikacija, govorni čin

\section{UVODNO O GRAMATICI I PRAGMATICI}

Kako je iz samoga naslova vidljivo, ovaj je rad pokušaj određenja elemenata koje bismo mogli nazvati pragmatičkima u gramatičkim opisima hrvatskoga jezika u radovima Ive Pranjkovića. Zadatak nije nimalo lak s obzirom na 
činjenicu da je Pranjković velik dio svoga znanstvenoga rada posvetio upravo gramatičkim opisima hrvatskoga jezika, pa je korpus koji smo si ovim radom zadali, a s obzirom na izrazitu znanstvenu plodnost Ive Pranjkovića, prilično opsežan. Stoga ovaj rad ne treba shvatiti kao temeljitu korpusnu analizu pragmatičkih elemenata, već kao naznaku općenitih pragmatičkih tendencija u pojedinim Pranjkovićevim radovima, a to su: Gramatika hrvatskoga jezika, Hrvatska skladnja, Gramatika u riječima i riječi u gramatici i Gramatička značenja.

U svrhu je navedenoga smjera promišljanja ponajprije potrebno odrediti na što točno mislimo kada kažemo pragmatički elementi. Naime svima nam je poznato da pragamatika/pragmalingvistika nema jedinstvenu definiciju, a njezina se neodređenost/neodredivost proteže do te mjere da neki autori (npr. Bar-Hillel, May i dr.) njezino područje bavljenja nazivaju pragmatičkim košem za otpatke. Drugim riječima, pragmatici se pripisuje sve ono što se nalazi izvan dosega isključivo strukturnim pristupima limitiranih jezičnih disciplina i što se zbog nemogućnosti provođenja empirijske provjere dugo vremena "bacalo u koš" te se doslovno smatralo neznanstvenim. Iako se dakle pragmalingvističkim pristupima od samih početaka odricala znanstvenost, a to se ponekad čini još i danas, neosporno je da se pragmatika, još otkako ju je Morris ${ }^{1}$ postulirao kao treću dimenziju (pored sintaktičke i semantičke) opisa jezičnoga znaka, ne da izgurati iz toga trodimenzionalnog modela.

Ovdje ćemo pragmatičke elemente odrediti kao one pojavnosti u gramatičkim opisima gdje se govori o (živoj, stvarnoj) komunikaciji, gdje se pretpostavlja neko zajedničko znanje sugovornika, gdje se u gramatičke opise uključuju odnosi među korisnicima jezičnih znakova i komunikacijski kontekst.

Gramatiku općenito možemo pojmiti kao opis određenih pravila prema kojima funkcionira jezik kao sustav, ali ujedno i kao propis određenih pravila prema kojima treba funkcionirati jezik kao standard. Takav propis zapravo je uputa za pravilnu uporabu jezičnih elemenata, a kada govorimo o uporabi, dakako, u kakvoj komunikacijskoj situaciji, ne možemo ne primijetiti da

\footnotetext{
I sam je Morris, tvorac pragmalingvistike, upravo kao i kasnije tradicionalni gramatičari, smatrao da je puno jednostavnije opisivati jezične znakove u okviru sintakse negoli određivati karakterizaciju uporabe znakova u određenim okolnostima ili pri opisivanju procesa koji se događaju u njihovim korisnicima. Carnap je pak bio mišljenja da sintaktičke i semantičke strukture prvo treba istražiti na pragmalingvističkoj osnovi, a potom im se posvetiti bez uzimanja konteksta i korisnika u obzir (usp. i Lewandowski 1984: 20).
} 
smo se time već “opasno” približili pragmalingvističkoj razini. Dakle naše je polazište da se gramatički opisi jezika ne mogu posve odijeliti od pragmatičkoga (komunikacijskog) utjecaja. ${ }^{2}$ Gramatičar se tako pri gramatičkim opisima, bio on toga svjestan ili ne, nalazi pred izazovom adekvatna opisa dijela jezičnoga sustava, a takav opis pak ne može kvalitetno provesti ako u obzir ne uzme i čimbenike koji se bez sumnje nalaze u samoj strukturi jezičnoga sustava i čimbenike uvjetovane komunikacijskim procesima (Lewandowski 1984: 12). Jasno je pritom da će se takvi pragmatički utjecaji izraženije pokazivati u sintaktičkim negoli primjerice morfološkim opisima, ali ni ondje nisu posve isključeni, primjerice u opisima zamjenica i načinima njihove uporabe u obraćanju. Općenito uzevši, možemo reći da se određene gramatičke pojave ne mogu potpuno ili čak uopće opisati ako se u obzir ne uzmu pragmatički aspekti, a to su prvenstveno: podjela rečenice na obavijesni subjekt (temu) i obavijesni predikat (remu), upotreba rečeničnoga modusa, modalni glagoli, modalne riječi i modalne čestice, vremenski i mjesni prilozi, zamjenice (ibid: 17).

\section{GRAMATIKA HRVATSKOGA JEZIKA}

$\mathrm{Na}$ samom početku pozabavit ćemo se pragmatičkim elementima upravo u Gramatici hrvatskoga jezika, koju je Pranjković napisao u suautorstvu s Josipom Silićem, te ćemo pokušati odrediti pojavljuju li se oni i u kojoj mjeri upravo u ovim gore navedenim gramatičkim opisima. Sami pak autori naglašavaju da se njihova gramatika ne temelji na gramatičkim opisima jezika kao standarda, već jezika kao sustava, zbog čega je nikako ne smijemo interpretirati kao gore spomenutu uputu za uporabu, međutim kako ćemo vidjeti, u njoj ima elemenata koji se opisuju upravo u kontekstu svoje uporabe u realnoj komunikaciji.

Već u samom Predgovoru u nekoliko se navrata spominje komunikacija (točnije, realna komunikacija) kao dimenzija koja je uzeta u obzir u grama-

\footnotetext{
2 Jedan od prvih europskih lingvista koji je zastupao takvo mišljenje svakako je lenjingradski germanist Admoni koji je veliku važnost davao kreativnoj realizaciji potencijala jezičnoga sustava te je tvrdio da od gramatičkih oblika i kategorija proizlaze perspektive i projekcije na sve načine uporabe jezika te da je temeljna zadaća gramatičara upravo određivanje tih perspektiva. Doduše, pritom je bio svjestan da opis svih projekcija koje proizlaze iz gramatičkih oblika nije moguć bez ostatka jer pri samom pokušaju određenja i opisa mogu nastati nove projekcije (usp. Lewandowski 1984: 20).
} 
tičkim opisima koji slijede. Tako primjerice autori najavljuju da se pri opisu vidskoznačenjskih čimbenika u glagola utvrdilo da "u realnoj komunikaciji postoji potreba za trima fazama (usp. sjeći - presjeći - presijecati)" (SilićPranjković 2005: 6). Nadalje spominju kako na rečeničnoj razini razlikuju "rečenicu kao jezičnu (gramatičku) jedinicu i iskaz kao govornu (komunikacijsku) jedinicu", s čim u vezi spominju i komunikacijsko ustrojstvo iskaza (temu i remu) (ibid: 7). Na samom kraju Predgovora autori naznačuju da su primjeri koje navode modelskoga tipa, ali i to da su ipak "nastojali da oni budu što bliži realnoj komunikaciji” (ibid.). Iz ovih se nekoliko kratkih, naizgled uzgrednih napomena, već može naslutiti da će ta gramatika u svojim opisima ponuditi svojevrstan odmak od dotadašnjih hrvatskih gramatičkih priručnika, a uzimanje u obzir realne komunikacije, dakle promatranje gramatičkih elemenata u govorenom jeziku, definitivno baca novo svjetlo na tako često poimanje Pranjkovića kao nepokolebljiva strukturalista.

Iz pragmalingvističke perspektive svakako je zanimljiva interpretacija zamjenica u istom priručniku, gdje se one nazivaju "situacijskim riječima jer se njihovo značenje utvrđuje govornom situacijom”. Tako (neke) zamjenice upućuju na konkretne osobe ili predmete koji su vidljivi/poznati komunikacijskim partnerima, a podjela zamjenica izvodi se "s obzirom na ono na što upućuju” (ibid: 117), dakako, u situacijskom kontekstu. Nadalje autori govore o uporabi ličnih zamjenica, pri čemu se navode (barem) dva neosporno pragmalingvistička aspekta: u prvom je riječ o tome da se "nenaglašeni oblici zamjenica rabe kada su uvjetovani kontekstom ili situacijom”, a u drugom je riječ o načinu obraćanja, dakle o socijalnoj konstrukciji odnosa među sugovornicima pri načinu uporabe zamjenice $V i$, pri čemu se kao konkretan primjer navodi obraćanje pojedincima u službenim dopisima te u obraćanju primjerice pape vjernicima, gdje se ukazuje na svečani čin, u kojemu se zamjenica $m i$ piše velikim početnim slovom.

Kako smo već ranije naveli, interpretacije onoga čime se pragmalingvistika točno bavi različite su i opsegom i djelomično sadržajem, no izvan svake je sumnje to da je pragmalingvistika prva jezična disciplina koja je, kako ju je već i sam Morris odredio, u obzir uzela odnos između jezičnoga znaka i njegova korisnika. U tom je smislu definicija čestica ili partikula primjer par excellence pragmatičkoga elementa u gramatičkom opisu: "Čestice ili partikule suznačne su i nepromjenjive riječi kojima se izražava stav govornika prema sadržaju cijeloga iskaza ili prema njegovu dijelu [...]" (ibid: 253). U kontekstu se uporabe pojedinih tipova čestica u nekoliko navrata spominje njihova uloga u razgovornome stilu te "iskazima, 
posebice dijaloškoga i/ili razgovornoga tipa" (npr. čestice eto, hajde i dr.) (ibid: 257). Na sličan se način pragmalingvistički elementi očituju i pri opisima uzvika (usput budi primijećeno, oni su, kao i čestice, svoje mjesto našli u sintaktičkim, a ne morfološkim gramatičkim opisima, kako je to bio običaj u dotadašnjim gramatikama), riječi "kojima se izražava u prvome redu subjektivna modalnost, $\mathrm{tj}$. odnos govornika prema sadržaju iskaza, $\mathrm{i}$ to u pravilu odnos emocionalne naravi" (npr. divljenje, zluradost, negodovanje, sumnjičavost itd.). Te riječi "služe kao svojevrsni signali (a ne znakovi) govornikova raspoloženja [...]. Značenje je tih riječi stoga [...] uvjetovano kontekstom ili situacijom u kojima se takve riječi upotrebljavaju." Osim toga autori navode da su uzvici po svojoj funkciji slični vokativu, tj. da "služe za uspostavljanje kontakta među sugovornicima, za pozivanje sugovornika na komunikacijski čin”. Tako za uspostavljanje komunikacijskoga čina, odnosno pozivanje sugovornika na sudjelovanje u komunikaciji prije svega služe zapovjedni uzvici, koji su ujedno i najsličniji vokativu ( $h e j, e j$, oj itd.). Posebnu vrstu uzvika čine onomatopeje, dakle "uzvici kojima se oponašaju zvukovi ili šumovi u prirodi, posebno oni koji dolaze do izražaja u međuljudskoj komunikaciji, a nisu jezični znakovi” (ibid: 258-260).

Nadalje, očekivano, pragmatički se elementi pronalaze u poglavlju naslovljenom Rečenica i iskaz, gdje se polazi od strukturalističkoga razlikovanja pojmova jezik i govor, da bi se ustanovilo važno razlikovanje između rečenice i iskaza utemeljeno na gramatičkome ustrojstvu, odnosno na činjenici da elementi gramatičkoga ustrojstva iskaza mogu biti implicitni, tj. sadržani u situacijskom kontekstu, pri čemu se oni "podrazumijevaju iz govorne situacije" (ibid: 278). Iako ta tvrdnja nije eksplicitno iskazana u opisima ovoga poglavlja, jasno je da autori polaze od toga da govorna situacija podrazumijeva i određene konverzacijske implikature, koje se temelje na nekom dijeljenom znanju sugovornika, dakle podrazumijeva zajedničku komunikacijsku osnovu koja osigurava sporazumijevanje, a takva je zajednička komunikacijska osnova element proučavanja pragmalingvistike.

U istom se poglavlju govori i o priopćajnoj svrsi kao elementu koji svaka rečenica mora sadržavati. Priopćajna svrha podrazumijeva "obavijest o tome želi li govornik sugovornika o čemu obavijestiti, dobiti od njega kakvu obavijest ili sudionika govornoga čina potaknuti, motivirati na govorni ili kakav drugi čin, izraziti svoj odnos (npr. emocionalni) prema onome što se priopćuje, reagirati na kakvu dobivenu obavijest ili sl." (ibid: 281). O istim elementima iskaza može se govoriti i iz pragmalingvističke perspektive, $\mathrm{s}$ tim da se oni tada imenuju ilokucijom, tj. snagom iskaza (obavijest, pitanje, 
naredba itd.) i perlokucijom, tj. efektom na sugovornika koji želimo postići nekim svojim verbalnim iskazom. Pritom ovdje posebno izdvajamo usklične rečenice, kojima "se prenosi obavijest o odnosu (ponajprije emocionalnom) između govornika i sadržaja obavijesti ili između govornika i sugovornika" (ibid: 281), a u kontekstu se uskličnih rečenica govori i o njihovoj primarnoj funkciji, pri čemu one osim što su usklične mogu biti primarno izjavne (To je predivno!) i primarno upitne (Kako je to moguće?!). Takva primarna značenjska obilježja upravo neodoljivo podsjećaju na primarnu i sekundarnu ilokuciju u pragmalingvističkim opisima, gdje formalno ustrojstvo kakve rečenice ima jedan tip obilježja (npr. upitnost), a njezin je smisao drukčiji i može označavati npr. naredbu (Koliko ti još puta moram reći da pospremiš svoju sobu?).

Sličan pragmalingvistički aspekt gramatičkoga opisa nalazimo u potpoglavlju naslovljenom Obavijesno ustrojstvo iskaza, gdje se upravo izrijekom govori da "rečenica s istim gramatičkim ustrojstvom može, kad postane kontekstualno uključena, imati različite varijante komunikacijskih jedinica (iskaza)" (ibid: 282). U tom se kontekstu govori o već ranije naznačenim pojmovima teme i reme, čiji opseg značenja ovisi izravno o kontekstu.

Govorni se činovi, kao jedan od temeljnih pojmova pragmalingvističkih opisa, u ovoj gramatici izrijekom spominju i u opisima predikatnih kategorija, konkretno u okviru kategorije vremena, kojom se "uspostavlja vremenski odnos između događaja označena rečenicom i govornoga čina". Dakle ovisno o vremenskom trenutku u kojem se odvio događaj opisan rečenicom u odnosu na sam govorni čin predikat će dobiti oznaku prošlosti, sadašnjosti ili budućnosti (ibid: 287).

Kako smo ranije naveli, pragmatički se elementi trebaju potražiti i u opisima glagolskoga modusa, tj. predikatne kategorije načina, koja se u Silić-Pranjkovićevoj Gramatici određuje kao odnos između onoga o čemu se priopćuje rečenicom $i$ stvarnosti. Tu je posebice zanimljivo razlikovanje objektivne i subjektivne modalnosti, pri čemu subjektivna modalnost "podrazumijeva odnos sudionika govornoga čina, posebice govornika, prema onome o čemu je u rečenici riječ" (ibid.).

\section{HRVATSKA SKLADNJA}

Kako znamo, znanstveni je rad Ive Pranjkovića vrlo opsežan i nije se zaustavio na upravo opisanoj Gramatici, pa se ovdje moramo osvrnuti i na neke druge njegove gramatičke opise u kojima se pojavljuju pomaci 
prema komunikaciji, odnosno u kojima možemo govoriti o pragmatičkim elementima. U Hrvatskoj skladnji autor govori o "takozvanim samostalnim članovima rečenice" (Pranjković 2002: 99) te u tom kontekstu spominje vokativ i njegovu funkciju obraćanja, dakle "uspostavljanja (verbalnog) kontakta sa sugovornikom i sugovornicima, odnosno pozivanje sugovornika na sudjelovanje u komunikacijskom činu". Autor pritom naglašava da bi se funkcija vokativa zapravo mogla smatrati i nekom vrstom Jakobsonove fatičke funkcije, čime se opet jasno i nedvojbeno krećemo u pragmalingvističkom smjeru. Međutim da ne bismo pomislili kako je autor u nekim segmentima svojih gramatičkih promišljanja "izdao" svoju vokaciju prvenstveno gramatičara, moramo navesti i to da ih on, iako govori o obavijesnom smislu takvih struktura, uvijek pokušava sagledati iz sintaktičke perspektive, da ne kažemo upravo vratiti ih na sintaktičku razinu, pa za vokativ kaže i to da "predstavlja rečenicu bez eksplicitno izraženog gramatičkog ustrojstva (bez eksplicirane predikativnosti)" (ibid.) te da bi zapravo bilo opravdano to "konstantno značenje obraćanja [...] smatrati čak i gramatičkim jer je kategorijsko, tj. svojstveno vokativu i samo njemu" (ibid: 101). ${ }^{3}$

Drugi se blagi pomak prema pragmalingvističkom dakle komunikacijskom poimanju nekih jezičnih struktura u istom poglavlju realizira u opisima struktura s modifikatorima, i to posebice onih u kojima modifikatori nemaju eksplicitne predikativnosti dakle u formalnom smislu ne predstavljaju rečenice, već imaju funkciju rečeničnoga priloga (npr. Zaludu! Sve su manje njegovi ljudi i predmeti) (ibid: 103). Pranjković napominje kako u tradicionalnoj domaćoj sintaktičkoj literaturi nije baš bilo pokušaja opisivanja takvih struktura, posebice ako nisu bile odvojene točkom, već su predstavljale kakve uvodne riječi/uvodne konstrukcije, te ako im se i posvećivala kakva pozornost, onda su bile imenovane krnjim, eliptičnim rečenicama, besubjektnim rečenicama itd. U tom kontekstu on nudi rješenje pozivajući se na spoznaje iz novijih istraživanja, naime nudi razlikovanje rečenice kao formalnojezične jedinice i rečenice kao komunikativne jedinice; ovoj potonjoj je, kako smo već ranije vidjeli, smisao, dakle predikativnost, uvjetovana kontekstualno ili situacijski. U tom je smislu modifikatore koji nemaju ekspliciranu predikativnost potrebno "promatrati i analizirati najprije s komunikativnog aspekta” (ibid: 104, 105).

U tom se kontekstu možemo zapitati o odnosu gramatikalizacije i pragmatikalizacije, konkretno, proizlazi li potencijalno gramatičko značenje obraćanja u vokativu iz njegove funkcije ili obrnuto. Drugim riječima, postavlja se pitanje je li pragmatikalizacija samo vrsta gramatikalizacije ili je riječ o zasebnoj pojavi (usp. Mroczynski 2012: 38). 


\section{GRAMATIKA U RIJEČIMA I RIJEČI U GRAMATICI}

Iako sam naslov ove knjige upućuje na gramatičke opise riječi, u pojedinim se poglavljima susreću izrazito pragmalingvistički elementi, dakako, ponovno u onim gramatičkim opisima koji ne bi bili mogući bez uključivanja komunikacijskoga aspekta. Izrazito pragmalingvistička obilježja nosi poglavlje Načini izražavanja imperativnosti, napisano u suautorstvu s Ladom Badurinom (pri čemu sam Pranjković kaže da se upravo njezin doprinos prvenstveno odnosi na neke pragmatičke aspekte tekstova koje su pisali u suautorstvu). Kako je već utvrđeno kada smo govorili o pitanjima vokativa u gramatičkom priručniku, imperativ mu je vrlo blizak te se kao i vokativ tijesno vezuje uz sam govorni čin, dakle izrazito je pragmatične naravi. Zbog te se karakteristike imperativ ne može smatrati modusom (načinom) u strogom smislu riječi, već je on "u tijesnoj vezi s kategorijom modalnosti, i to tzv. subjektivnom modalnosti, dakle onom koja pretpostavlja odnos između sadržaja komunikacije i sudionika govornoga čina" (Pranjković 2016: 31, 32). U vezi s iskazivanjem imperativnosti autori posebno napominju tzv. indirektne govorne činove (ibid: 43), odnosno one iskaze u kojih formalne karakteristike ukazuju na jednu funkciju, a njihovo komunikacijski uvjetovano značenje na kakvu drugu. Pritom je riječ o različitoj ilokuciji (komunikacijskom smislu) iskaza, što primjerice vidimo u iskazima tipa Hoćeš li već jednom prestati?, gdje formalne karakteristike ukazuju na upitnost, a sadržajne na imperativnost, tj. od sugovornika se nikako ne očekuje odgovor na pitanje, već mu se implicitno izdaje naredba da prestane s radnjom koju upravo izvodi. U vezi je s takvim, kako ih autori nazivaju, kontekstualnim imperativima i pojam uljudnosti, koji je izrazito pragmalingvistički pojam, te autori navode različite načine (mahom formalno upitnoga tipa) na koje se imperativnost iskazuje u strategijama uljudnosti. Pritom se imperativnost realizira u različitim vrijednosnim nijansama, točnije u različitim ilokucijskim snagama iskaza, "koje se mogu kretati u široku rasponu od blage sugestije, prijedloga ili savjeta, preko molbe i upozorenja do prijetnje, naredbe ili zapovijedi" (ibid: 45, 46).

U uvodnom smo dijelu spomenuli pojam pragmatičkoga koša za otpatke, u kojemu je završavalo sve ono što su tradicionalni gramatički opisi zanemarivali jer nisu imali alata kojima bi pristupili takvim pitanjima - te je pojave itekako svjestan i Pranjković, koji je jedno poglavlje ove knjige posvetio komunikacijskom aspektu gramatičkoga opisa. Pritom se posebice pozabavio elementima koji "služe za modifikaciju rečeničnih struktura, za intenzifikaciju pojedinih članova rečeničnoga ustrojstva, za promjenu 
komunikacijske perspektive rečenice odnosno iskaza i sl.” (ibid: 63). To su primjerice određeni rečenični prilozi (npr. nažalost), koji nisu dio rečeničnoga ustrojstva, a modificiraju sadržaj rečenice, potom pojedini padeži poput vokativa (čija je temeljna funkcija, kako smo već utvrdili, pozivanje sugovornika na komunikacijski čin) i dativa (tj. onih oblika dativa koji "modificiraju sadržaj cijele rečenice, a ne pripadaju njezinu gramatičkom ustrojstvu", dakle ne predstavljaju objekt, priložnu oznaku ni atribut, npr. To je meni glupo), uzvici i pitanja. Pitanja su prema svojoj komunikacijskoj ulozi slična ostalim elementima kojima se sugovornik izravno poziva na kakav oblik komunikacijske suradnje, konkretno, njima se od sugovornika traži obavijest. No za razliku od ostalih funkcionalno sličnih oblika "pitanja su usmjerena i na sugovornika i na sadržaj informacije” (ibid: 65-67).

Kako je autor u predgovoru ove knjige i sam najavio, njezin se sadržaj tiče i gramatičkih i pragmatičkih opisa svojstava suznačnih riječi, pa se u njoj našlo i jedno, usudili bismo se reći, čisto pragmatičko poglavlje, u kojemu se pokušava uspostaviti tipologija iskaza u hrvatskome jeziku. Autor u svojim razmatranjima polazi od činjenice da se rečenica može promatrati i kao apstraktna i kao aktualizirana jedinica te se posebice posvećuje opisivanju ove potonje. Pritom se hvata ukoštac s pragmalingvističkim terminom govornoga čina i njegovih sastavnica (lokucije, ilokucije i perlokucije), posebice izdvaja performative, tj. performativne glagole, te ih u ostinovskom smislu određuje kao elemente "koji uz verbalni aspekt sadrže i aspekt djelovanja". Potom donosi svoj prijedlog podjele iskaza na asertivne, interogativne, imperativne, komisivne, koncesivne, ekspresivne i performativne (ibid: 205, 206).

Pragmatički se elementi neizbježno pojavljuju i u poglavlju $O$ dijalogu, napisanom u suautorstvu s Ladom Badurinom, kao i u poglavlju o Ujevićevim psiholingvističkim razmišljanjima, gdje se između ostaloga govori i o uporabi eufemizama, napose onoj "nečasnoj”, pri čemu se u obzir nužno uzima moralna cenzura, odnosno primjerenost ili neprimjerenost kakva izraza u određenoj situaciji (ibid. 236).

\section{GRAMATIČKA ZNAČENJA}

Pragmalingvističkih elemenata moguće je naći i u knjizi Ive Pranjkovića naslovljenoj Gramatička značenja, za koju sam autor kaže da je "izrazito komplementarna" s već gore djelomično analiziranom Gramatikom, s tom razlikom da se u ovoj knjizi određene gramatičke kategorije "stavljaju u kon- 
tekst širih, semantičkih i(li) logičkih" (Pranjković 2013: 6), a dodali bismo ovdje, i pragmatičkih kategorija. Ovaj se naš dodatak prvenstveno odnosi na prvo poglavlje u knjizi, nazvano Gramatika govornika i sugovornika. U njemu autor već na samom početku konstatira ono što smo naveli u uvodu ovoga rada, naime to da su "mnoge gramatičke pojavnosti [...] manje ili više vezane za govorni čin, odnosno za sudionike govornoga čina" (ibid: 9). Pritom je na prvom mjestu potrebno spomenuti kategoriju lica, za koju autor navodi da je od svih kategorija najtješnje vezana uz govorni čin. Naime kategorija lica uspostavlja odnose među sudionicima komunikacije na način da određuje poziciju govornika, sugovornika i onoga trećega, kako autor kaže, "nesudionika govornoga čina" (ibid: 10). Dakako, uz kategoriju lica tijesno su vezane i zamjenice, za koje smo već ranije konstatirali da su pragmatički vrlo relevantne jer uspostavljaju odnose između jezičnoga i izvanjezičnoga. Osim kategorije lica i uz nju tijesno vezane uporabe zamjenica autor uz govorni čin vezuje i kategoriju načina (posebice tzv. subjektivnog načina, npr. optativa, ali i objektivnog načina, "kojim se daje obavijest o tome je li ono o čemu se priopćuje stvarno, samo moguće (potencijalno) ili nemoguće (nestvarno, irealno)") (ibid: 14). Svoje mjesto u pragmatičkom pristupu gramatičkim pojavnostima svakako pronalaze i imperativ, vokativ, pitanja te čestice (pragmemi), o kojima je i ranije već bilo riječi.

Pragmalingvistički se elementi pronalaze i u opisima kategorija vremena i prostora koje se smatraju jezičnim univerzalijama, a autor je u ovoj knjizi kategoriji vremena posvetio i zasebno poglavlje jer, kako sam navodi, svaki se "govorni čin mora odvijati u nekom vremenu pa za nj vrijeme odnosno vremenska relacija između govornoga čina i onoga o čemu se u njemu priopćuje mora biti relevantna" (ibid: 25 ).

\section{ZAKLJUČAK}

U gore provedenoj analizi vidjeli smo da se pri opisima gramatičkih jedinica, posebice onih na sintaktičkoj razini, načelno polazi od toga da se pojedini gramatički element ne može smatrati izoliranim sintaktičkim modulom (kako su to primjerice zamišljali generativisti), već da se svaki takav element može shvatiti kao svežanj obilježja relevantnih za više lingvističkih razina (morfologiju, sintaksu, semantiku i pragmatiku). Možemo reći da se gramatičko znanje govornika konstituira na temelju svakodnevne komunikacije, dakle da nije urođeno. Neki autori u tom smislu dolaze do zaključka da gramatička 
jedinica ne predstavlja jednoznačni omjer forme i funkcije, već služi kao orijentacijski obrazac za komunikacijsko djelovanje (npr. Günthner 2009; Mroczynski 2012).

Kako znamo, Ivo Pranjković slovi kao vrstan gramatičar, prvenstveno sintaktičar, no kako smo ovdje mogli vidjeti, ni pragmalingvistički elementi nisu mu nimalo strani, pa iako se on možda i sam smatra strukturalistom, možemo ustvrditi da je u nekim svojim radovima apsolutno nadišao vlastiti znanstveni identitet.

\section{LITERATURA}

Bar-Hillel, Yehoshua. 1971. Out of Pragmatic Wastebasket. "Linguistic Inquiry” 2(3), The MIT Press Journals, 401-407.

Grice, Paul. 1989. Studies in the Way of Words, London: Harvard University Press.

Günthner, Susanne. 2009. Konstruktionen in der kommunikativen Praxis. Zur Notwendigkeit einer interaktionalen Anreicherung konstruktionsgrammatischer Ansätze. "Zeitschrift für germanistische Linguistik", sv. 37, 402-426.

Heine, B., Claudi, U., F. Hünnemeyer. 1991. Grammaticalization: A Conceptual Framework, Chicago: University of Chicago Press, 2 vols.

Lewandowski, Theodor. 1984. Pragmatische Aspekte in Grammatiken des Deutschen. Stickel, Gerhard (ur.) Pragmatik in der Grammatik. Jahrbuch des Insitituts für deutsche Sprache, Schwann: Mannheim.

May, L. Jacob. 2001. Pragmatics: An Introduction, Oxford: Blackwell Publishing.

Mroczynski, Robert. 2012. Grammatikalisierung und Pragmatikalisierung, Tübingen: Narr Verlag.

Pranjković, Ivo. 2002. Hrvatska skladnja. Rasprave iz sintakse hrvatskoga standardnog jezika, Zagreb: Hrvatska sveučilišna naklada.

Pranjković, Ivo i Josip Silić. 2005. Gramatika hrvatskoga jezika za gimnazije i visoka učilišta, Zagreb: Školska knjiga.

Pranjković, Ivo. 2013. Gramatička značenja, Zagreb: Matica hrvatska.

Pranjković, Ivo. 2016. Gramatika u riječima i riječi u gramatici, Zagreb: Matica hrvatska. Searle, John Rogers. 1969. Speech Acts, London: Cambridge University Press. 


\section{SUMMARY \\ PRAGMATICS IN IVO PRANJKOVIĆ'S GRAMMAR}

At first glance it may seem that the grammatical and the pragmatic approach to a linguistic phenomenon have nothing in common, and that it is impossible to combine them. However, if we delve deeper into the grammatical descriptions of linguistic units on the morphological and the syntactic levels, we find that sometimes it is necessary to view certain elements in a wider context, i.e. that it is necessary to take into account their communicative context in order to describe them adequately. This paper therefore focuses on the identification of those elements, in Pranjković's various grammatical descriptions of language, which Pranjković himself claimed needed to be approached from a different perspective, namely the pragmalinguistic one. : Such an approach to individual grammatical descriptions, especially those that can be found in grammar books, is definitely a novelty in Croatian linguistics.

Key words: pragmatics, grammar, communication, speech act 